\title{
Pubertal adipose tissue: is it really necessary for normal sexual maturation?
}

\author{
A Galler, V Schuster and W Kiess \\ Children's Hospital, University of Leipzig, Oststr. 21-25, D-04317 Leipzig, Germany \\ (Correspondence should be addressed to A Galler; Email: gala@medizin.uni-leipzig.de)
}

The relation between fat metabolism and the reproductive axis in humans has long been recognized. Girls with anorexia nervosa or those undergoing intense physical training, such as ballet dancers, are known to develop reproductive dysfunction. This consists of either delayed menarche or secondary amenorrhea. In the 1970s this frequently observed relationship between weight and age at menarche was put together by Frisch as the socalled 'critical weight hypothesis', which states that a certain amount of body fat seems to be required for the process of initiating normal reproductive function $(1,2)$. Further studies have shown that energy deficiency (lack of fat) is accompanied by suppression of hormones of the reproductive axis. Both anorexia nervosa and intense physical training are associated with reduced gonadotropin levels. Therefore there is a clear link between peripheral energy stores (provided as adipose tissue) and regulation of physical development and reproductive capacity $(2,3)$.

However, Frisch's original concept has repeatedly been challenged. To further question this concept we report on a 16-year-old girl who proceeded normally through puberty with a body mass index (BMI) much below the third percentile for her age. Examination revealed an extremely lean adolescent girl with a height of $163 \mathrm{~cm}$ (30th percentile) and a body weight of $32.1 \mathrm{~kg}$ (10 kg below the third percentile), with pubertal stages B4 and P4 according to Tanner at the age of 16 years. BMI was $12.1 \mathrm{~kg} / \mathrm{m}^{2}$. She had had her menarche at the age of 15 years and her menstrual cycle had been regular since that time. Extensive investigation of the patient including rheumatological tests and screening of metabolic disorders did not reveal any abnormalities. The girl revealed a marfanoid habitus and additionally exhibited multiple congenital contractures, anomalies of the ears and marked osteoporosis. Accordingly, congenital contractural arachnodactyly (CCA, Beals syndrome, MIM 121050) was diagnosed. Considering the research over the last years showing that one of the key players in the central regulation of reproductive development may be leptin, we investigated the plasma leptin level of our patient. The serum leptin level of our patient, determined by RIA, was $1.55 \mathrm{ng} / \mathrm{ml}$. With respect to her BMI, her age and pubertal stage, this leptin serum concentration lies well within the upper normal range (4).
Cloning of the gene defective in obese ob/ob mice identified the ob gene product leptin as a hormone that serves as a messenger between the peripheral adipose tissue and the brain. Leptin is mainly produced by adipocytes. It is well documented that its serum levels correlate tightly with body fat mass (4). Leptin appears to play an important role in the regulation of appetite and food intake and in reproduction as well. Leptindeficient mice (ob/ob mice) are infertile, and if treated with exogenous leptin become fertile and may bear normal offspring (5). This has led to the conclusion that leptin plays a key role in the reproductive axis. Ongoing research has also clearly suggested that leptin is required for appropriate pubertal development. There is, however, controversy as to leptin's direct role in reproduction. In particular, it is still unclear whether it could serve either as a permissive or as a triggering signal of puberty. It has been postulated that raising leptin levels under favorable nutritional conditions could suppress neuropeptide Y (NPY) activity and release the inhibitory effects of NPY neurons upon the gonadotropin-releasing hormone-luteinizing hormonefollicle-stimulating hormone (GnRH-LH-FSH) axis $(5-7)$.

Summarizing the data from the literature and the findings in our patient, we suggest that leptin rather than weight is indeed the 'critical factor' of the Frisch hypothesis. Leptin should be considered at least as permissive as weight for normal pubertal development in women. In fact, despite low BMI, puberty can progress if there is sufficient leptin production to signal to the brain readiness for reproductive functions, as shown in the patient reported here.

\section{References}

1 Frisch RE, Wyshak G \& Vincent L. Delayed menarche and amenorrhea in ballet dancers. New England Journal of Medicine 1980303 17-19.

2 Frisch RE. Pubertal adipose tissue: is it necessary for normal sexual maturation? Federation Proceedings 198039 2395-2400.

3 Clarke IJ \& Henry BA. Leptin and reproduction. Reviews of Reproduction $1999448-55$.

4 Blum WF, Englaro P, Hanitsch S, Juul A, Hertel NT, Muller J et al. Plasma leptin levels in healthy children and adolescents: dependence on body mass index, body fat mass, gender, pubertal stage, 
and testosterone. Journal of Clinical Endocrinology and Metabolism 199782 2904-2910.

5 Hileman SM, Pierroz DD \& Flier JS. Leptin, nutrition, and reproduction: timing is everything. Journal of Clinical Endocrinology and Metabolism $200085808-814$.

6 Flier JS. Clinical review. What's in a name? In search of leptin's physiological role. Journal of Clinical Endocrinology and Metabolism $1998831407-1413$.
7 Kiess W, Müller G, Galler A, Reich A, Deutscher J, Klammt J et al. Body fat mass, leptin and puberty. Journal of Pediatric Endocrinology and Metabolism 200013 717-722.

Received 23 August 2001

Accepted 23 August 2001

www.eje.org 